Check for updates

Cite this: RSC Adv., 2019, 9, 23450

Received 7th June 2019

Accepted 19th July 2019

DOI: $10.1039 / c 9 r a 04300 d$

rsc.li/rsc-advances

\title{
Keggin-structure heteropolyacid supported on alumina to be used in trans/esterification of high- acid feedstocks $\dagger$
}

\author{
Leyvison Rafael V. da Conceição, (D) ab Cristiano E. R. Reis, (D) ${ }^{a}$ Rosemar de Lima, ${ }^{a}$ \\ Daniela V. Cortez (D) and Heizir F. de Castro (D) *a
}

\begin{abstract}
Heteropolyacids (HPA) with Keggin structures, such as $\mathrm{H}_{3} \mathrm{PMO}_{12} \mathrm{O}_{40}\left(\mathrm{H}_{3} \mathrm{PMO}\right)$, have been described as efficient catalysts in trans/esterification reactions due to their tolerance to water and free fatty acids contents, with particularly well-suited characteristics of high proton mobility and stability. The versatile array of HPA is considerably increased when such catalysts are supported onto solid matrices. In this sense, $\mathrm{Al}_{2} \mathrm{O}_{3}$ was assessed as support for $\mathrm{H}_{3} \mathrm{PMo}$ to be used in trans/esterification reactions to produce biodiesel from high-acid feedstocks. The catalyst structure was characterized and applied on trans/ esterification reaction of acid oils using ethanol as acyl acceptor. A face centered composite design was employed to conduct the experimental design and results analysis, taking macaw palm oil as study model. The process achieved an optimum level of $99.8 \%$ ester content and $4.1 \mathrm{~mm}^{2} \mathrm{~s}^{-1}$ viscosity under the following reaction conditions: $190{ }^{\circ} \mathrm{C}$ reaction temperature, $50: 1$ ethanol-to-oil molar ratio and $13.0 \%$ catalyst concentration. Other tested feedstocks (fungal single cell oil and residual frying oil) were also tested promoting satisfactory results, though the parameters were found to be slightly outside the limits set by the USA (ASTM D6715) standard. The $\mathrm{H}_{3} \mathrm{PMO} / \mathrm{Al}_{2} \mathrm{O}_{3}$ catalyst presented good regeneration and can be reused for up to four reaction cycles and requires lower ethanol-to-oil ratio, temperature, and catalyst concentration in comparison with other data from the literature.
\end{abstract}

\section{Introduction}

The utilization of heteropolyacids (HPA) as catalysts has attracted interest from both Academic and Industrial settings due to their versatility and ease of use in acid catalysis. HPA with Keggin structures, such as $\mathrm{H}_{3} \mathrm{PW}_{12} \mathrm{O}_{40}, \mathrm{H}_{4} \mathrm{SiW}_{12} \mathrm{O}_{40}, \mathrm{H}_{3} \mathrm{PMo}_{12} \mathrm{O}_{40}$, and $\mathrm{H}_{4} \mathrm{SiMo}_{12} \mathrm{O}_{40}$, have been described to be efficiently used in trans/ esterification reactions due to their high water and free fatty acid tolerance, with particularly well-suited characteristics of high proton mobility and stability due to their strong Brønstedprofile. ${ }^{1}$ Despite the numerous advances over the past years, a few challenges remain as the focus of study, particularly increasing the thermal stability, specific area, and solubility in polar media. The versatile array of HPA is considerably increased when such catalysts are supported onto solid matrices, such as activated carbon, ${ }^{2}$ zirconia, ${ }^{3}$ silica, ${ }^{4}$ and niobia. ${ }^{5}$

The characteristics of the support have some direct implications on the performance of the HPA catalyst. While zirconia and

${ }^{a}$ Engineering School of Lorena-University of São Paulo, 12602-810, Lorena, São Paulo, Brazil.E-mail: heizir@usp.br

${ }^{b}$ Institute of Exact and Natural Sciences, Federal University of Pará, 66075-110, Belém, Brazil

$\dagger$ Electronic supplementary information (ESI) available. See DOI: $10.1039 / \mathrm{c} 9 \mathrm{ra} 04300 \mathrm{~d}$ titanium-based oxides have been demonstrated to be excellent supports for HPA, ${ }^{6}$ the use of such catalysts is hindered by the costs associated with the matrices, which often affect the economics of bulk-production chemicals, such as biodiesel. On the other hand, the use of lower-cost supports, such as alumina, have been linked to higher observable leaching effects, as demonstrated by Sheikh et al., ${ }^{6}$ who demonstrated that 12tungstophosphoric acid supported on $\mathrm{Al}_{2} \mathrm{O}_{3}$ leached at a higher rate when compared to the same HPA supported on $\mathrm{ZrO}_{2}$ and $\mathrm{SiO}_{2}$. However, many of the expected outcomes on the utilization of HPA supported on $\mathrm{Al}_{2} \mathrm{O}_{3}$ are not optimized in the literature and are often discredited when compared to other supports in screening studies. In this sense, this study aims to synthesize, characterize and optimize the performance of a 12-phosphomolybdic acid catalyst supported on aluminum oxide $\left(\mathrm{H}_{3} \mathrm{PMo} / \mathrm{Al}_{2} \mathrm{O}_{3}\right)$ through simultaneous esterification and transesterification reaction to produce biodiesel from high-acid feedstocks. A factorial design was used to determine optimal variable conditions, such as reaction temperature, alcohol-to-oil molar ratio and catalyst concentration, taking macaw palm oil as a study model. The established conditions were also applied to perform trans/esterifications of others high acid feedstocks, such as residual frying and microbial oils.

Ethanol was used as acyl acceptor due to some advantages when used in a process for biodiesel production. It has 
a superior dissolving power in vegetable oils and the ethyl esters (FAEE) show lower smoke opacity, lower exhaust temperature and lower pour point. ${ }^{7}$ Additionally, unlike methanol (which is generally derived from fossil sources), ethanol is produced mainly from renewable sources via fermentation processes, and because its large scale production as a substitute fuel for gasoline already exists, the supply of bioethanol for the industrial production of biodiesel can be easily achieved. ${ }^{7,8}$

\section{Experimental}

\section{Materials}

Macaw palm oil was supplied by the Association of Small Farmers D'Antas (Minas Gerais, Brazil). Residual Frying Oil (RFO) was obtained from a local vendor and was filtered to remove food and other particulates. Fungal Single Cell Oil (SCO) was obtained from the culture of Mucor circinelloides URM 4182 in sugarcane vinasse. ${ }^{9}$ The characterization in regards to fatty acid distribution and acidity of the used oils is described in Table 1. Aluminum oxide (Calcined Alumina A-1) containing $98.8 \% \mathrm{Al}_{2} \mathrm{O}_{3}$ and with surface area of $67.70 \mathrm{~m}^{2} \mathrm{~g}^{-1}$ was donated by Alcoa Alumínio S.A. (Poços de Caldas, Minas Gerais, Brazil), and was calcined at $300{ }^{\circ} \mathrm{C}$ for $3 \mathrm{~h}$ before use. 12-Molybdophosphoric acid $\left(\mathrm{H}_{3} \mathrm{PMo}_{12} \mathrm{O}_{40}\right)$ and anhydrous ethanol $(98.0 \%)$ were purchased from the Vetec ${ }^{\circledR}$ Sigma-Aldrich. All the other chemical reagents and solvents were of analytical grade and used without further purification.

\section{Preparation of the HPA catalyst}

$\mathrm{H}_{3} \mathrm{PMo} / \mathrm{Al}_{2} \mathrm{O}_{3}$ was prepared via incipient-wetness impregnation. In a typical synthesis, the heteropolyacid mass was dissolved in an alcoholic solution $70 \mathrm{wt} \%$ at room temperature, transferred to a ceramic crucible containing the support $\left(\mathrm{Al}_{2} \mathrm{O}_{3}\right)$ and then mixed. The solid formed was then dried at $100{ }^{\circ} \mathrm{C}$ for $30 \mathrm{~min}$, followed by calcination at $300^{\circ} \mathrm{C}$ for 2 cycles of $1 \mathrm{~h}$, followed by a final cycle of $3 \mathrm{~h} . \mathrm{H}_{3} \mathrm{PMo} / \mathrm{Al}_{2} \mathrm{O}_{3}$ catalysts were prepared using three different impregnation concentrations, 10, 20 and $30 \mathrm{wt}$.

Table 1 Characterization of the oil feedstock used in the trans/ esterification reactions

\begin{tabular}{llll}
\hline & \multicolumn{2}{l}{ Oil source } & \\
\cline { 2 - 4 } Fatty Acid (\%) & Macaw palm & RFO & Fungal SCO \\
\hline C8:0 & - & - & 1.64 \\
C10:0 & - & - & 1.57 \\
C12:0 & - & 3.69 & 9.32 \\
C14:0 & - & - & 5.76 \\
C16:0 & 18.7 & 20.62 & 35.11 \\
C16:1 & 4.0 & - & 2.96 \\
C18:0 & 2.8 & 2.51 & 2.3 \\
C18:1 & 53.4 & 27.75 & 21.06 \\
C18:2 & 17.7 & 43.71 & 10.99 \\
C18:3 & 1.5 & 1.72 & 9.28 \\
Saturated fatty acids (\%) & 21.5 & 26.8 & 55.7 \\
Monounsaturated fatty acids (\%) & 57.4 & 27.8 & 24.02 \\
Polyunsaturated fatty acids (\%) & 19.2 & 45.4 & 20.27 \\
Acidity (mg KOH g ${ }^{-1}$ ) & 39.0 & 3.94 & 67.4
\end{tabular}

$\mathrm{H}_{3} \mathrm{PMo} \%$ relative to the support. The catalysts were subjected to the analysis of surface acidity and preliminary catalytic tests performed under fixed reaction conditions: temperature of $175{ }^{\circ} \mathrm{C}$, ethanol-to-oil molar ratio of $40: 1$ and catalyst concentration of $10.0 \%$, in order to evaluate the catalytic activity and to determine the best impregnation concentration of the catalyst to be employed throughout the study.

\section{Catalytic reaction}

The performance of the catalyst prepared with the selected $\mathrm{H}_{3}$ PMo impregnation was evaluated by simultaneous esterification and transesterification reactions of all feedstocks with ethanol. Before the reactions, the catalyst was thermally activated at $120{ }^{\circ} \mathrm{C}$ for $2 \mathrm{~h}$. All catalytic tests were performed on pressurized stainless steel reactor (Parr Series 5500 HPCL Compact Reactors) equipped with an electrical heating jacket covering the reaction vessel. The reaction time and agitation parameters were set at $4 \mathrm{~h}$ and $700 \mathrm{rpm}$, respectively.

Taking the macaw palm oil as study model, the effects of the process variables: reaction temperature $\left(X_{1}\right)$ from 100 to $200{ }^{\circ} \mathrm{C}$, ethanol-to-oil molar ratio $\left(X_{2}\right)$ from $20: 1$ to $60: 1$ and catalyst concentration $\left(X_{3}\right)$ from 5.0 to $15.0 \mathrm{wt} \%$ (oil basis) were evaluated on response variables: ester content $\left(Y_{1}\right)$ and viscosity $\left(Y_{2}\right)$. The data were analyzed using Statistica $13 \AA$ and the coefficients were interpreted using Fisher's test. The accuracy and general ability of these polynomial models were evaluated by the coefficients of determination $R^{2}$. A 95\% significance level $(p<0.05)$ was applied for all analyses.

\section{Downstream process and catalyst stability}

At the end of the runs performed with macaw palm and residual frying oils, the catalyst was separated from the reaction mixture by centrifugation at $1570 \times g$ for $15 \mathrm{~min}$. The reaction mixture was transferred to a separatory funnel and washed with portions of hot distilled water $\left(80^{\circ} \mathrm{C}\right)$ for $12 \mathrm{~h}$ to allow separation between the ethyl esters and glycerol phases. This washing step was performed three times to ensure complete glycerol removal. Finally, the ethyl esters were dried with anhydrous sodium sulfate to remove residual water. ${ }^{\mathbf{1 0}}$ It is important to mention that crude biodiesel from microbial oil a dry washing using Amberlite was adopted following methodology described by Santos et al. ${ }^{\mathbf{1 1}}$

The stability of the recovered catalyst was evaluated in successive batch runs performed under optimal process condition using macaw palm oil as feedstock. The recovered catalyst was washed three times with $t$-butanol $(10 \mathrm{~mL})$, thermally activated at $120^{\circ} \mathrm{C}$ for $2 \mathrm{~h}$ and then used in another cycle under the same reaction conditions.

\section{Analytical methods}

The $\mathrm{N}_{2}$ adsorption-desorption isotherms were measured at $77 \mathrm{~K}$ by using a Nova 1000 mark Quantachrome. Before measurements, about $0.2 \mathrm{~g}$ of sample was pre-treated under $2 \mathrm{~h}$ vacuum at $200{ }^{\circ} \mathrm{C}$ for removal impurities adsorbed on the catalyst surface. The surface area measurements were calculated according to the standard Brunauer-Emmett-Teller method 
(BET), the pore diameter and volume were obtained by the Barret-Joyner-Halenda (BJH) method.

The surface acidity of the catalyst was determined using acidbase titration method. An aqueous suspension of $0.1 \mathrm{~g}$ of catalyst in $20 \mathrm{~mL}$ of $\mathrm{NaOH}\left(0.1 \mathrm{~mol} \mathrm{~L}^{-1}\right)$ was stirred for $3 \mathrm{~h}$ at room temperature. The suspension was centrifuged and the supernatant titrated with $\mathrm{HCl}$ solution $\left(0.1 \mathrm{~mol} \mathrm{~L}^{-1}\right)$ in the presence of phenolphthalein. The surface acidity of the catalysts was expressed in $\mathrm{mmol} \mathrm{\textrm {H } ^ { + }} \mathrm{g}^{-\mathbf{1}} .^{\mathbf{1 2}}$

X-ray diffraction (XRD) analysis of the synthesized catalyst was carried out using a PANalytical Model Empyrean X-ray diffractometer at $40 \mathrm{kV}$ and $30 \mathrm{~mA}$. $\mathrm{Cu} \mathrm{K \alpha}(1.541874 \hat{\mathrm{A}}) 2 \theta$ radiation was used at a range of $8-70^{\circ}$ to generate diffraction patterns at ambient temperature. The catalyst morphology was analyzed by a high-resolution scanning electron microscopy (SEM) on a LEO Model $1450 \mathrm{VP}$ microscope, operating at $20 \mathrm{kV}$ acceleration voltage. Fourier transforms infrared (FTIR) spectra were recorded on a PerkinElmer spectrometer model FTIR System Spectrum GX. Samples were pressed in $\mathrm{KBr}$, and the spectra obtained in the range of $4000-400 \mathrm{~cm}^{-1}$ with a resolution of $4 \mathrm{~cm}^{-1}$ over a sum of 32 scans.

The ester contents were analyzed by gas chromatography (Varian, model CP 3800) with a flame ionization detector (FID) using a TR FAME capillary column (30 m length, $0.25 \mathrm{~mm}$ internal diameter, and $0.25 \mu \mathrm{m}$ film thickness) following methodology described by Conceição et $a .^{\mathbf{1 2}}$ Methyl heptadecanoate (C17:0) was used as an internal standard reference. Ester content was expressed as mass fraction in terms of percentage. Viscosity was determined according to the standard method ASTM D 445 with a LVDVII Brookfield viscometer (Brookfield Viscometers Ltd, England) equipped with a CP 42 cone at $40{ }^{\circ} \mathrm{C}$ using $0.5 \mathrm{~mL}$ of sample. Density value was determined according to the standard method ASTM D 4052 with a DMA $35 \mathrm{~N}$ EX digital densimeter (Anton Paar) at $20{ }^{\circ} \mathrm{C}$ using $2 \mathrm{~mL}$ of sample. Residual acylglycerol contents were determined in an Agilent 1200 Series liquid chromatograph (Agilent Technologies, USA) equipped with an Evaporative Light Scattering Detector and a Gemini C-18 $(5 \mu \mathrm{m}, 150 \times 4.6 \mathrm{~mm}$, $110 \AA$ ) column at $40{ }^{\circ} \mathrm{C}$ following methodology described by Carvalho et al. ${ }^{13}$

\section{Results and discussion}

\section{Catalyst characterization and effect of HPA/support ratio}

Acidity is one of the most important property that a solid catalyst must have, especially when used in processes involving simultaneous esterification and transesterification reactions for biodiesel production. ${ }^{\mathbf{1 2}}$ Thus, catalyst performance at different $\mathrm{H}_{3} \mathrm{PMo}$ impregnation concentrations was used to determine suitable impregnation loading that could afford high conversion rate of macaw palm oil into ester. The surface acidity of catalysts shows a significant increase, as there is greater $\mathrm{H}_{3} \mathrm{PMo}$ impregnation. For instance, the surface acidity of the catalyst increased from 4.95 to $9.60 \mathrm{mmol} \mathrm{H}^{+} \mathrm{g}^{-1}$ when the ratio of $\mathrm{H}_{3} \mathrm{PMo} / \mathrm{Al}_{2} \mathrm{O}_{3}$ increased from 10 to $30 \mathrm{wt} \%$. The surface acidity follows a proportional behavior with the ratio of $\mathrm{H}_{3} \mathrm{PMo} / \mathrm{Al}_{2} \mathrm{O}_{3}$, as an intermediate measurement was made at $20 \mathrm{wt} \%$ ratio, which promoted a surface acidity of $6.30 \mathrm{mmol} \mathrm{H}^{+} \mathrm{g}^{-1}$, which fits within the limit readings of 10 and $30 \mathrm{wt} \%$. Under the investigated conditions (ethanol molar ratio $1: 60$, at $150{ }^{\circ} \mathrm{C}$ ), a moderate efficiency was attained with the catalyst being impregnated at $30.0 \% \mathrm{H}_{3} \mathrm{PMo}$, which provided biodiesel samples containing $80.0 \%$ ester and $6.7 \mathrm{~mm}^{2} \mathrm{~s}^{-1}$ viscosity. Interestingly, the impregnation of $\mathrm{H}_{3} \mathrm{PMo}$ onto $\mathrm{Al}_{2} \mathrm{O}_{3}$ provided a catalyst with greater acidity $\left(9.60 \mathrm{mmol} \mathrm{H}^{+} \mathrm{g}^{-1}\right)$ than values previously reported of $\mathrm{H}_{3} \mathrm{PMo}$ supported onto $\mathrm{Nb}_{2} \mathrm{O}_{5}$ (5.644 $\mathrm{mmol} \mathrm{H}^{+} \mathrm{g}^{-1}$ ) at the same ratio of $\mathrm{H}_{3} \mathrm{PMo}$ and mineral support (30 wt\%).

The XRD analysis was used to confirm whether $\mathrm{H}_{3}$ PMo was in its crystalline form or dispersed when supported. X-ray diffraction patterns of the $\mathrm{Al}_{2} \mathrm{O}_{3}$ support, pure $\mathrm{H}_{3} \mathrm{PMo}$ and $\mathrm{H}_{3} \mathrm{PMo} / \mathrm{Al}_{2} \mathrm{O}_{3}$ catalyst are shown in Fig. 1 . As it can be seen, curve (a) presents a typical XRD pattern of $\mathrm{Al}_{2} \mathrm{O}_{3}$ at $2 \theta$; according to Evangelista et al.,$^{14}$ values of $19.5^{\circ}, 32.5^{\circ}, 37.5^{\circ}, 39.5^{\circ}, 45.5^{\circ}$, $62.0^{\circ}$ and $67.4^{\circ}$ are characteristics of an amorphous, tetragonal and monophasic structure. The XRD diffractogram of pure $\mathrm{H}_{3}$ PMo has crystalline features with distinct diffraction planes and high intensities. The XRD pattern of pure $\mathrm{H}_{3} \mathrm{PMo}$ (curve (b)) revealed typical reflections of heteropolyacids by the presence of peaks at about $2 \theta$ values of $12.0^{\circ}, 18.0^{\circ}, 25.5^{\circ}, 26.0^{\circ}, 27.0^{\circ}, 28.0^{\circ}$, $30.5^{\circ}, 34.0^{\circ}$ and $35.5^{\circ}$, which are characteristics of crystalline $\mathrm{H}_{3} \mathrm{PMo}$. The XRD pattern of $\mathrm{H}_{3} \mathrm{PMo} / \mathrm{Al}_{2} \mathrm{O}_{3}$ catalyst shows features of both phases, i.e. the amorphous phase of alumina (amorphous halos) as well as peaks of crystalline phases of $\mathrm{H}_{3}$ PMo. In the curve analysis (c), it is possible to observe the presence of peaks of $\mathrm{H}_{3} \mathrm{PMo}$ crystalline phase at $12.0^{\circ}, 18.0^{\circ}$, $26.0^{\circ}, 28.0^{\circ}$ and $35.5^{\circ}$, i.e. the Keggin structure, as verified in the pure $\mathrm{H}_{3} \mathrm{PMo}$ diffraction pattern. This demonstrates that $\mathrm{H}_{3} \mathrm{PMo}$ was widely dispersed on the $\mathrm{Al}_{2} \mathrm{O}_{3}$ support.

SEM images of the $\mathrm{Al}_{2} \mathrm{O}_{3}$ support and $\mathrm{H}_{3} \mathrm{PMo} / \mathrm{Al}_{2} \mathrm{O}_{3}$ catalyst are exhibited in Fig. 2. The alumina support structure (Fig. 2(a)) is rough and contains pores that results in high specific surface area in which $\mathrm{H}_{3}$ PMo could be anchored, and reveal irregular particles with a non-uniform morphology of spherical agglomerates whose diameter ranges from 20 to $100 \mu \mathrm{m}$. The SEM image of the $\mathrm{H}_{3} \mathrm{PMo} / \mathrm{Al}_{2} \mathrm{O}_{3}$ catalyst (Fig. 2(b)) suggests that $\mathrm{H}_{3}$ PMo was widely dispersed throughout the alumina support surface, thus leading to specific surface area reduction and evidencing the impregnation success.

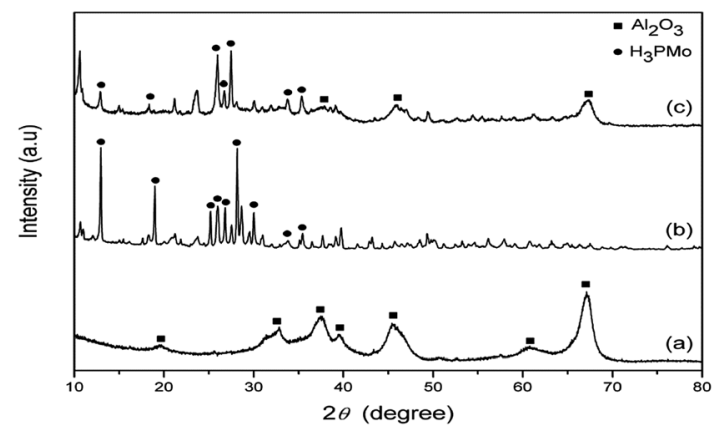

Fig. 1 XRD patterns of (a) $\mathrm{Al}_{2} \mathrm{O}_{3}$ support, (b) pure $\mathrm{H}_{3} \mathrm{PMo}$ and (c) $\mathrm{H}_{3} \mathrm{PMO} / \mathrm{Al}_{2} \mathrm{O}_{3}$. 

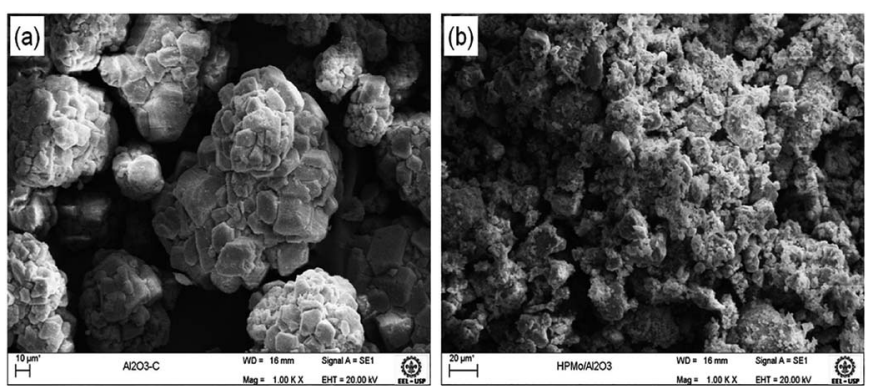

Fig. 2 SEM images of (a) $\mathrm{Al}_{2} \mathrm{O}_{3}$ support and (b) $\mathrm{H}_{3} \mathrm{PMO} / \mathrm{Al}_{2} \mathrm{O}_{3}$ catalyst.

The FTIR spectra of the $\mathrm{Al}_{2} \mathrm{O}_{3}$ support and $\mathrm{H}_{3} \mathrm{PMo} / \mathrm{Al}_{2} \mathrm{O}_{3}$ catalyst are displayed in Fig. 3, which shows a typical alumina infrared spectrum. For such a material, Al ions can occupy two sub lattices: tetrahedral sites and octahedral sites. The band close to $\sim 620 \mathrm{~cm}^{-1}$ is attributed to a stretching vibration of the $\mathrm{AlO}_{6}$ atomic group, while the a $\sim 800 \mathrm{~cm}^{-1}$ structure is a result of the $\mathrm{AlO}_{4}$ atomic group stretching which is the reason why the $\mathrm{Al}-\mathrm{O}$ bonds are shorter. ${ }^{15,16}$

The $\mathrm{H}_{3} \mathrm{PMo} / \mathrm{Al}_{2} \mathrm{O}_{3}$ catalyst spectrum shows four bands in the range of $1100-750 \mathrm{~cm}^{-1}$. Bands at 1065, 960, 870 and $795 \mathrm{~cm}^{-1}$ are characteristics of the Keggin structure, which are the result of $\nu_{\mathrm{as}}\left(\mathrm{P}-\mathrm{O}_{\mathrm{a}}\right), \nu_{\mathrm{as}}\left(\mathrm{Mo}-\mathrm{O}_{\mathrm{d}}\right), \nu_{\mathrm{as}}\left(\mathrm{Mo}-\mathrm{O}_{\mathrm{b}}-\mathrm{Mo}\right)$ and $\nu_{\mathrm{as}}\left(\mathrm{Mo}-\mathrm{O}_{\mathrm{c}}-\mathrm{Mo}\right)$, respectively, (in which $\mathrm{O}_{\mathrm{a}}$ is the oxygen atom bound to $3 \mathrm{Mo}$ atoms and the central $\mathrm{P}$ atom; $\mathrm{O}_{\mathrm{b}}$ and $\mathrm{O}_{\mathrm{c}}$ are the bridging oxygen atoms; and $\mathrm{O}_{\mathrm{d}}$ is the terminal oxygen atom). These absorption bands are consistent with previously reported data. ${ }^{17,18}$ The band at around $1635 \mathrm{~cm}^{-1}$ was equally pronounced in both materials, which was attributed to the $\mathrm{O}-\mathrm{H}$ stretching vibration.

Table 2 presents the values of BET surface areas, pore volume and average pore diameters for the $\mathrm{H}_{3} \mathrm{PMo} / \mathrm{Al}_{2} \mathrm{O}_{3}$ catalyst. Data indicate a remarkable decrease between the BET surface area value of the $\mathrm{Al}_{2} \mathrm{O}_{3}$ support $\left(67.70 \mathrm{~m}^{2} \mathrm{~g}^{-1}\right)$ and the $\mathrm{H}_{3} \mathrm{PMo} / \mathrm{Al}_{2} \mathrm{O}_{3}$ catalyst $\left(31.66 \mathrm{~m}^{2} \mathrm{~g}^{-1}\right)$ after impregnation, which was attributed to the effect of HPMo deposition on the support, thereby resulting in partial blocking of the porous network. However, this is an expected behavior of high HPMo loading at $30.0 \mathrm{wt} \%$. Similar discussion can be made to the pore volume of the

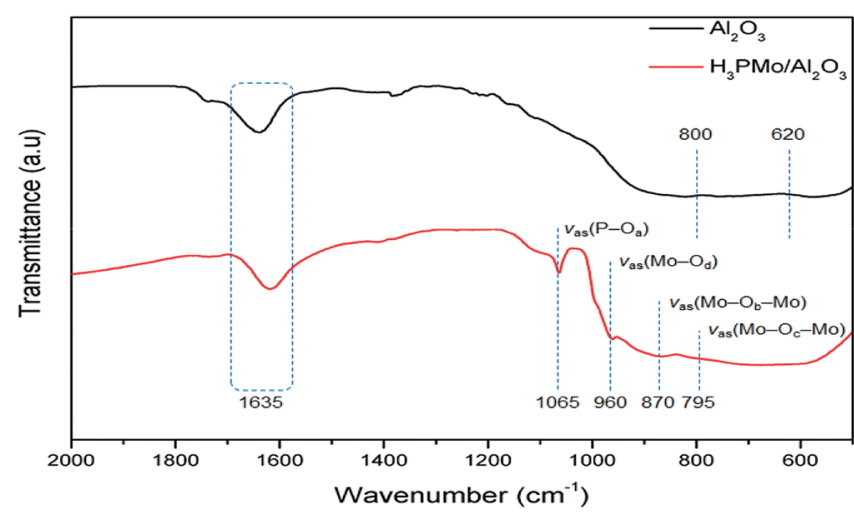

Fig. 3 FTIR spectra of the $\mathrm{Al}_{2} \mathrm{O}_{3}$ support and $\mathrm{H}_{3} \mathrm{PMo} / \mathrm{Al}_{2} \mathrm{O}_{3}$ catalyst.
Table 2 Textural and properties of $\mathrm{Al}_{2} \mathrm{O}_{3}$ support and $\mathrm{HPMO} / \mathrm{Al}_{2} \mathrm{O}_{3}$ catalyst

\begin{tabular}{llll}
\hline Sample & $\begin{array}{l}\text { Surface area } \\
\left(\mathrm{m}^{2} \mathrm{~g}^{-1}\right)\end{array}$ & $\begin{array}{l}\text { Pore size } \\
(\mathrm{nm})\end{array}$ & $\begin{array}{l}\text { Pore volume } \\
\left(\mathrm{cm}^{3} \mathrm{~g}^{-1}\right)\end{array}$ \\
\hline $\mathrm{Al}_{2} \mathrm{O}_{3}$ & 67.70 & 6.97 & 0.188 \\
$\mathrm{H}_{3} \mathrm{PMo} / \mathrm{Al}_{2} \mathrm{O}_{3}$ & 31.66 & 7.83 & 0.048
\end{tabular}

support and the catalyst, which decreased, respectively from $0.188 \mathrm{~cm}^{3} \mathrm{~g}^{-1}$ to $0.048 \mathrm{~cm}^{3} \mathrm{~g}^{-1}$, and the pore size, which increased from $6.97 \mathrm{~nm}$ to $7.83 \mathrm{~nm}$.

The $\mathrm{N}_{2}$ adsorption-desorption isotherms and pore size distribution for the $\mathrm{H}_{3} \mathrm{PMo} / \mathrm{Al}_{2} \mathrm{O}_{3}$ catalyst are shown in Fig. 4 . The isotherm (Fig. 4(a)) corresponded to type IV, according to the IUPAC classification, and showed a characteristic hysteresis loop $(\mathrm{H} 2)$ in a relative pressure $\left(P / P_{0}\right)$ range of $0.4-1.0$, which was due to capillary condensation taking place in the mesoporous material. Fig. 4(b) shows that a pore size distribution centered in the range of 3.0-16.0 $\mathrm{nm}$ is a typical characteristic of a mesoporous material. ${ }^{19}$

\section{Statistical model determination}

Experimental points of both real and coded values are presented in Table 3, along with experimental results for ester content and viscosity value at specific design points. 18 runs were performed randomly in order to minimize errors from systematic trends in variables. The obtained data were examined by the analysis of variance (ANOVA) for fitting second-order response surface models by the least square method and to assess their goodness of fit. The models significance was evaluated by the probability value ( $p$-value); at 95\% confidence level, ( $p$-values of less than 0.05 indicate significant effects). Coefficient terms with $p$-values of over 0.05 were not significant, thus being removed from the regression models.

Statistical significance and fitness of the developed equations as well as the effects of individual terms and their interactions were analyzed by the ANOVA as summarized on Table 4 . The models quality of fit was evaluated by Fisher's test ( $F$-value), the probability value ( $p$-value) and determination coefficients.
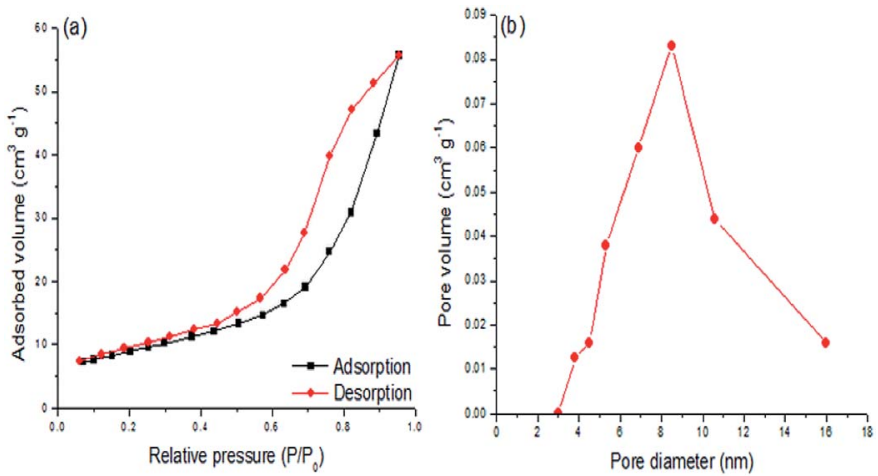

Fig. 4 (a) $\mathrm{N}_{2}$ adsorption-desorption isotherms and (b) pore size distribution of the $\mathrm{H}_{3} \mathrm{PMO} / \mathrm{Al}_{2} \mathrm{O}_{3}$ catalyst. 
Table 3 Experimental design matrix for the simultaneous esterification and transesterification of macaw palm oil

\begin{tabular}{|c|c|c|c|c|c|}
\hline \multirow[b]{2}{*}{ Run } & \multicolumn{3}{|l|}{ Variables } & \multicolumn{2}{|l|}{ Responses } \\
\hline & Temp. $\left({ }^{\circ} \mathrm{C}\right)$ & $\begin{array}{l}\text { EtOH : oil } \\
\left(\mathrm{mol} \mathrm{mol}{ }^{-1}\right)\end{array}$ & Catalyst (oil wt\%) & Ester content (\%) & Viscosity $\left(\mathrm{mm}^{2} \mathrm{~s}^{-1}\right)$ \\
\hline 1 & 100 & 20 & 5 & 3.20 & 38.45 \\
\hline 2 & 100 & 20 & 15 & 12.70 & 29.9 \\
\hline 3 & 100 & 60 & 5 & 12.85 & 27.9 \\
\hline 6 & 200 & 20 & 15 & 95.75 & 6.00 \\
\hline 7 & 200 & 60 & 5 & 96.55 & 5.35 \\
\hline 8 & 200 & 60 & 15 & 98.80 & 5.15 \\
\hline 9 & 100 & 40 & 10 & 13.70 & 31.4 \\
\hline 10 & 200 & 40 & 10 & 96.05 & 5.85 \\
\hline 11 & 150 & 20 & 10 & 93.25 & 6.35 \\
\hline 16 & 150 & 40 & 10 & 82.00 & 6.70 \\
\hline 17 & 150 & 40 & 10 & 83.05 & 6.90 \\
\hline 18 & 150 & 40 & 10 & 81.25 & 7.15 \\
\hline
\end{tabular}

Based on the coded parameters, quadratic regression models with determined coefficients are given by eqn (1) and (2)

$$
\begin{aligned}
Y_{1} & =83.1+42.1 X_{1}-29.3 X_{1}^{2}+2.4 X_{2}+10.6 X_{2}^{2}+4.6 X_{3} \\
& -10.9 X_{3}^{2}-1.3 X_{2} X_{3} \\
Y_{2} & =7.2-25.7 X_{1}+22.2 X_{1}^{2}-2.6 X_{2}-2.2 X_{2}^{2}-2.5 X_{3} \\
& +2.9 X_{3}^{2}+2.3 X_{1} X_{2}+1.6 X_{1} X_{3}+2.5 X_{2} X_{3}
\end{aligned}
$$

Data on Table 4 show that both models presented high $F$ values, i.e. 88.20 ester content and 93.22 viscosity with very low $p$-values (both $<0.0000$ ), thereby indicating that both predictive quadratic models were highly significant for the experimental data. The models significance and adequacy were also tested by using the determination coefficient $\left(R^{2}\right)$ and adjusted determination coefficient $\left(R_{\mathrm{adj}}{ }^{2}\right)$. Their $R^{2}$ and $R_{\mathrm{adj}}{ }^{2}$ values were very high, $R^{2}=0.9900$ and $R_{\mathrm{adj}}{ }^{2}=0.9788$ (ester content) and $R^{2}$ $=0.9905$ and $R_{\text {adj }}{ }^{2}=0.9800$ (viscosity). These values suggest that both models explain $98 \%$ of the experimental data variability on average (only $2 \%$ variation in ester content and viscosity could not be explained by the developed models), thence evidencing high significance of the models and an excellent correlation between predicted and observed values, as it can be seen in Fig. S1 (ESI $\dagger$ ).

Interactive effects of process variables on responses variables were studied by plotting three-dimensional surface curves versus two independent variables, while keeping another variable at their central (0) level. 3D curves of ester content and viscosity from the interactions between variables are shown in Fig. 5.

Table 4 ANOVA results for the fitted second-order polynomial models ${ }^{a}$

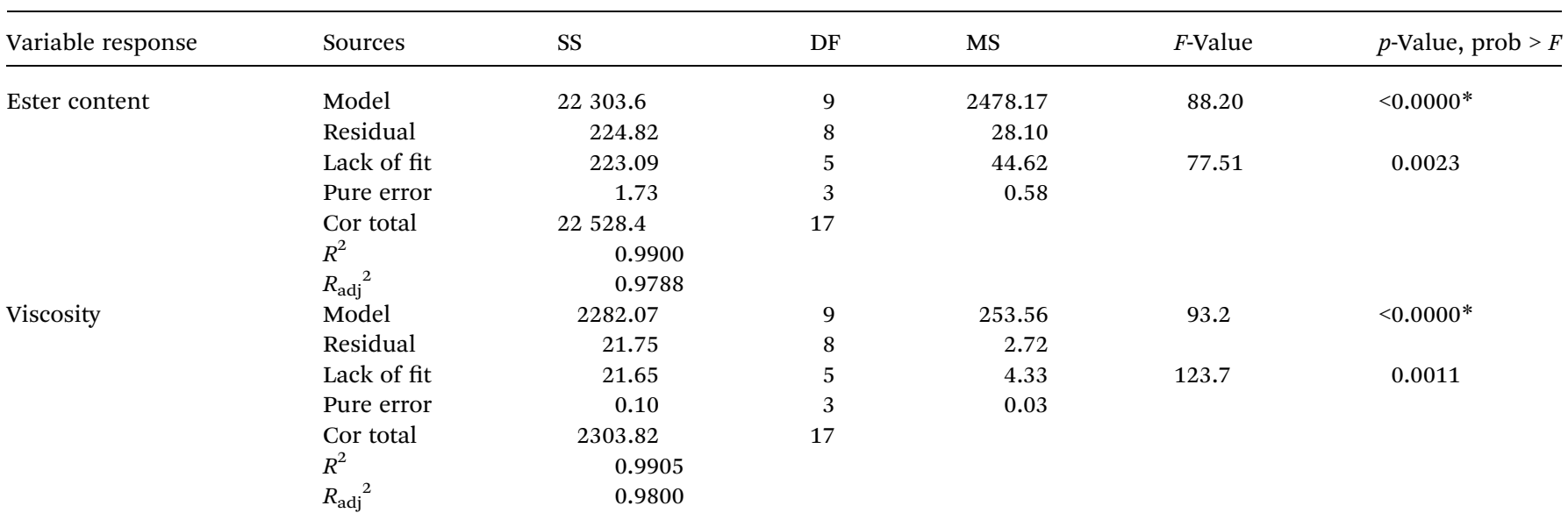

${ }^{a} \mathrm{SS}=$ sum of squares, $\mathrm{DF}=$ degree of freedom, MS $=$ mean squares. 

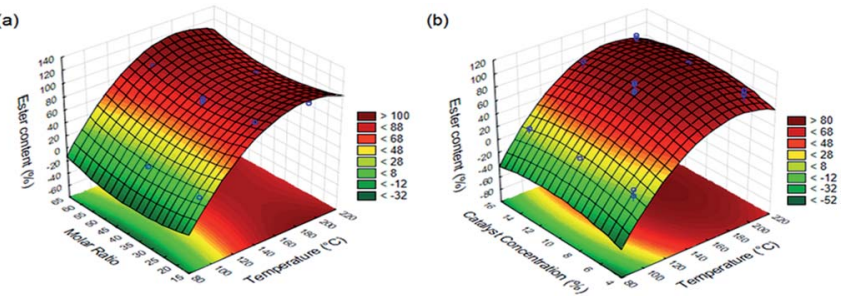

(c)

(d)
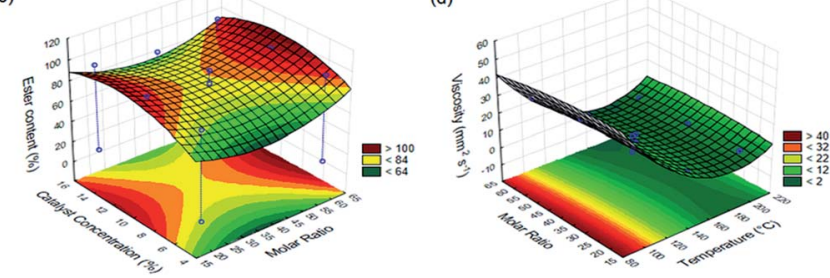

(e)

(f)

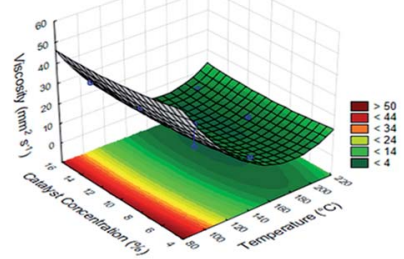

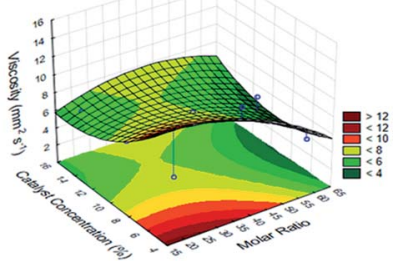

Fig. 5 3D Response surface and contour plots for ester content vs. (a) temperature and molar ratio (b) temperature and catalyst concentration, (c) molar ratio and catalyst concentration, and for viscosity vs. (d) temperature and molar ratio, (e) temperature and catalyst concentration, (f) molar ratio and catalyst concentration.

The 3D curves of ester content and viscosity from the interactions between variables are shown in Fig. 5. Fig. 5(a) demonstrates the effect of an interaction between independent variables of reaction temperature and ethanol-to-oil molar ratio on ester content at a constant catalyst concentration of $10.0 \%$. Based on the surface plot, it can be observed that the independent variable of reaction temperature exerts a great influence on ester content, since an increase in reaction temperature values leads to biodiesel having significantly higher ester content. Ester content values of over $98.0 \%$ are obtained by any value used in the molar ratio variable, however, reaction temperature at or greater than $180{ }^{\circ} \mathrm{C}$ must necessarily be set. Fig. 5(b) shows the response surface and contour plots for the combined effect of reaction temperature and catalyst concentration on ester content at a constant ethanol-to-oil molar ratio of $40: 1$. The results demonstrate that ester content increases as temperature and catalyst concentration also increase. Ester content values (higher than 98.0\%) were obtained when reaction temperature and catalyst concentration were close to $180{ }^{\circ} \mathrm{C}$ and $12.0 \%$, respectively. Fig. 5(c) shows the effect of ethanol-to-oil molar ratio and catalyst concentration on ester content, while keeping reaction temperature at $150{ }^{\circ} \mathrm{C}$. The same Fig. 5(c) shows that high ester contents are obtained by selecting values that are close to low and high levels of ethanolto-oil molar ratio, 20:1 and 60:1, respectively, along with catalyst concentrations between 8.0 and $12.0 \%$. However, ester content values of over $98.0 \%$ are achieved when using an ethanol-to-oil molar ratio of $60: 1$ and catalyst concentration of

$11.0 \%$. Fig. 5(d) represents the effect of varying reaction temperature and ethanol-to-oil molar ratio on biodiesel viscosity at a constant catalyst concentration of $10.0 \%$. It clearly shows that the influence of temperature is statistically significant over the studied experimental range, which has a positive influence on biodiesel viscosity (low values are desired) as reaction temperature increased, regardless of the molar ratio being used. The biodiesel viscosity decreased to approximately $4.0 \mathrm{~mm}^{2} \mathrm{~s}^{-1}$ when reaction temperature was between 170 and $190{ }^{\circ} \mathrm{C}$ at whatever molar ratio. Fig. 5(e) shows the viscosity response for interactive factors of catalyst concentration and reaction temperature at a constant ethanol-to-oil molar ratio of $40: 1$. A significant decreased in the biodiesel viscosity (reaching values of around $4.0 \mathrm{~mm}^{2} \mathrm{~s}^{-1}$ ) was observed when the catalyst concentration increased from 10.0 and $14.0 \%$ and temperature raised from 170 and $190{ }^{\circ} \mathrm{C}$. On the other hand, it was noted that the biodiesel viscosity tends to increase under extreme conditions, for example by processing the reaction at catalyst concentrations of over $14.0 \%$ and reaction temperatures above $190{ }^{\circ} \mathrm{C}$. Fig. 6(f) represents the dependency of biodiesel viscosity on both ethanol-to-oil molar ratio and catalyst concentration at a constant reaction temperature of $150{ }^{\circ} \mathrm{C}$. The lowest biodiesel viscosity values $\left(4.0-5.0 \mathrm{~mm}^{2} \mathrm{~s}^{-1}\right)$ were obtained by processing the reaction at a molar ratio of $60: 1$ and intermediate values for catalyst concentration of around $10 \%$.

An optimization process was also carried out by Derringer's desirability function. ${ }^{20}$ The general function optimization procedure is used to find optimal conditions of independent variables (within the specified experimental range) for overall response desirability. Both ester content and viscosity responses were simultaneously optimized by this desirability function. The data described in the ESI $\dagger$ show the set of desirability graphs for the responses. For the ester content response variable, any value of over $95.0 \%$ satisfies the desirability, thus the value of 1 was selected. In regards to the viscosity response variable, satisfactory values are those below $6.0 \mathrm{~mm}^{2} \mathrm{~s}^{-1}$, hence 1 was attributed to this value. Based on the RSM analyses and

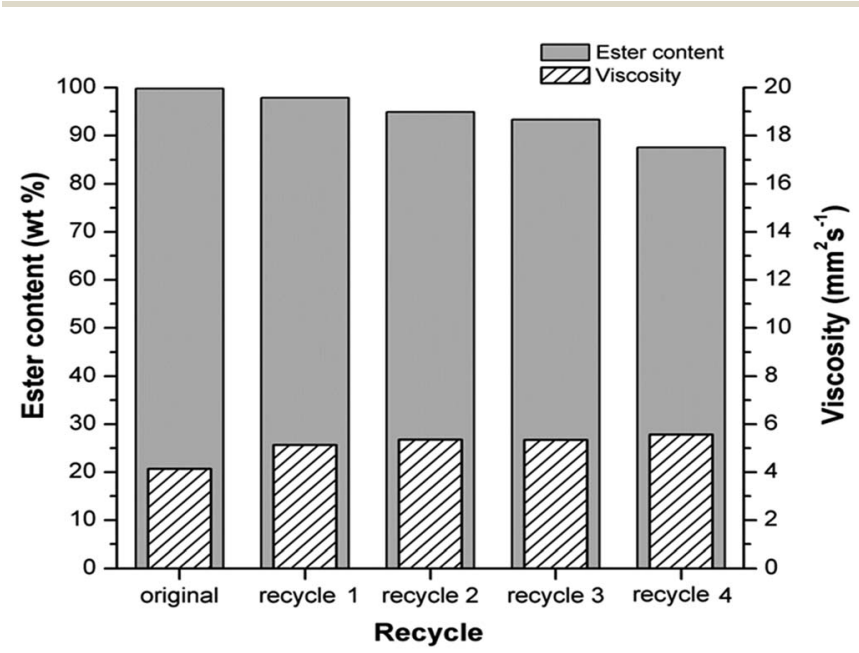

Fig. 6 Reusability study of $\mathrm{H}_{3} \mathrm{PMo} / \mathrm{Al}_{2} \mathrm{O}_{3}$ catalyst. Reaction conditions: temperature at $190^{\circ} \mathrm{C}$, ethanol-to-oil molar ratio of $50: 1$ and catalyst concentration of $13.0 \%$. 
desirability results optimum conditions of the macaw palm biodiesel production at the studied variables are: reaction temperature of $190{ }^{\circ} \mathrm{C}$, ethanol-Ester content and viscosity responses predicted under these conditions were $99.8 \%$ and 4.1 $\mathrm{mm}^{2} \mathrm{~s}^{-1}$, respectively.

The models were verified as regards their predictability by analyzing the residual plots that are resulted from the difference between actual and predicted values of responses (ester content and viscosity). This analysis was carried out by using the normal probability plot of residual, residual $v s$. run orders and residual $v s$. the predicted response (ESI $\dagger$ ). In order to evaluate the quality of the biodiesel produced under optimal process conditions, some properties were analyzed and the results met the specification of biodiesel (B100) standardized by international agencies, including USA (ASTM D6715) and Brazil (ANP $45 / 2014$ ). In addition to excellent ester content and viscosity presented by macaw palm ethyl biodiesel, low values of monoacylglycerol and absence of diacylglycerol are extremely important for product quality, which indicate optimal conversion of oil into biodiesel. These contaminant values are very low and do not affect properties such as density, which was $880 \mathrm{~kg} \mathrm{~m}^{-3}$, which is within the limits established by the same standards.

\section{Application of the catalyst on other feedstocks}

The optimized conditions were applied on trans/esterification reactions of residual frying oil and fungal single cell oil with ethanol as acyl acceptor in order to verify the robustness of the catalyst and the statistical model developed using macaw palm oil as feedstock. The two tested oils have been described in the literature as highly acidic, ${ }^{\mathbf{2 1 , 2 2}}$ which often pose additional difficulty in the trans/esterification reaction. The optimized results, using a catalyst ratio of $13 \mathrm{wt} \%$, ethanol-to- oil molar ratio of $50: 1$, reaction time of $4 \mathrm{~h}$, and temperature of $190{ }^{\circ} \mathrm{C}$. Results are shown in Table 5.

The results demonstrate that the optimized conditions provided satisfactory conversions of other oil feedstocks to ethyl esters. The conversion of SCO to FAEE is often limited by the viscosity of the oil and the presence of other lipid materials, which are not saponifiable. ${ }^{23}$ The residual products of the trans/ esterification of SCO to biodiesel were mainly monoacylglycerols (4.82 wt\%), with a minor amount of diacylglycerols (0.79 wt $\%)$, demonstrating that a possible increase in the reaction time would likely provide greater conversion yields, and subsequently lower viscosity values for such ester mixtures.
The conversion of residual frying oil, on the other hand, was likely to be limited to the water content of the feedstock, similar to what has been described in the literature. ${ }^{24}$ While there were only monoacylglycerols present as residual ester products (3.99 wt\%) from the reaction of residual frying oil to ethyl esters, the ester mixture presented a relatively high acid value $(0.92 \mathrm{mg}$ $\mathrm{KOH} \mathrm{g}^{-1}$ ), indicating that a possible water activity in the oil likely provided hydrolysis of the esters, generating free fatty acids in the medium.

Therefore, while the catalyst prepared showed certain robustness towards the conversion of other oils of high acid value, the utilization of SCO and RFO as feedstocks for FAEE production was partially limited due to factors that are not present in macaw palm oil. Nonetheless, the results are promising and demonstrate that the reaction conditions can be extrapolated to other feedstock.

\section{Catalyst recycling and comparison of operational conditions for similar reactions}

One of the most important factors of heterogeneous catalysts that contribute to catalytic performance is stability against deactivation and leaching of the active sites during the reaction. Three consecutive catalytic cycles of simultaneous esterification and transesterification reactions were carried out under the optimal reaction conditions established by this work (temperature of $190{ }^{\circ} \mathrm{C}$, ethanol-to-oil molar ratio of $50: 1$ and catalyst concentration of $13.0 \%$ ). After the end of the first run, the used catalyst was removed from the reaction mixture by centrifugation, and then washed with $t$-butanol three times to eliminate both polar and non-polar compounds adsorbed on the catalyst surface. Then the recovered catalyst was dried at $120{ }^{\circ} \mathrm{C}$ and used for the second, third and fourth catalytic cycles, respectively, under the same experimental conditions and regeneration method (Fig. 6).

The $\mathrm{H}_{3} \mathrm{PMo} / \mathrm{Al}_{2} \mathrm{O}_{3}$ catalyst showed good catalytic stability by maintaining ester content of over $87.0 \%$, a reduction of approximately $12.0 \%$ from its original ester content and biodiesel viscosity below $6.0 \mathrm{~mm}^{2} \mathrm{~s}^{-1}$ after the fourth cycle. These results are consistent with data from an investigation conducted by Talebian-Kiakalaieh et al.,${ }^{25}$ whereby the catalyst was reused in four cycles for producing biodiesel from waste cooking oil with high free fatty acid content, which presented conversion reduction of approximately $15.0 \%$.

Table 5 Biodiesel quality parameter as a function of the feedstock

\begin{tabular}{lllll}
\hline Quality parameters & $\begin{array}{l}\text { Macaw palm } \\
\text { oil }\end{array}$ & $\begin{array}{l}\text { Fungal single } \\
\text { cell oil }\end{array}$ & $\begin{array}{l}\text { Residual frying } \\
\text { oil }\end{array}$ & $\begin{array}{l}\text { Standard value } \\
\text { specification (ANP }\end{array}$ \\
\hline Density $\left(\mathrm{kg} \mathrm{m}^{-3}\right)$ at $20^{\circ} \mathrm{C}$ & 880 & 915 & 870 & $860-900$ \\
Viscosity $\left(\mathrm{mm}^{-2} \mathrm{~s}^{-1}\right) 40^{\circ} \mathrm{C}$ & 4.2 & 6.8 & 6.0 & $1.9-6.0$ \\
Ester content $(\mathrm{wt} \%)$ & 98.80 & 94.39 & 96.01 & Min. 96.5 \\
Monoacylglycerol (wt\%) & 0.87 & 4.17 & 3.51 & Max. 0.7 \\
Diacylglycerol (wt\%) & 0.33 & 1.44 & 0.48 & Max. 0.2
\end{tabular}

${ }^{a}$ ANP: Brazilian National Agency of Petroleum, Natural Gas and Biofuels. 
Table 6 Examples of use of supported-HPMo catalysts in the production of methyl and ethyl esters

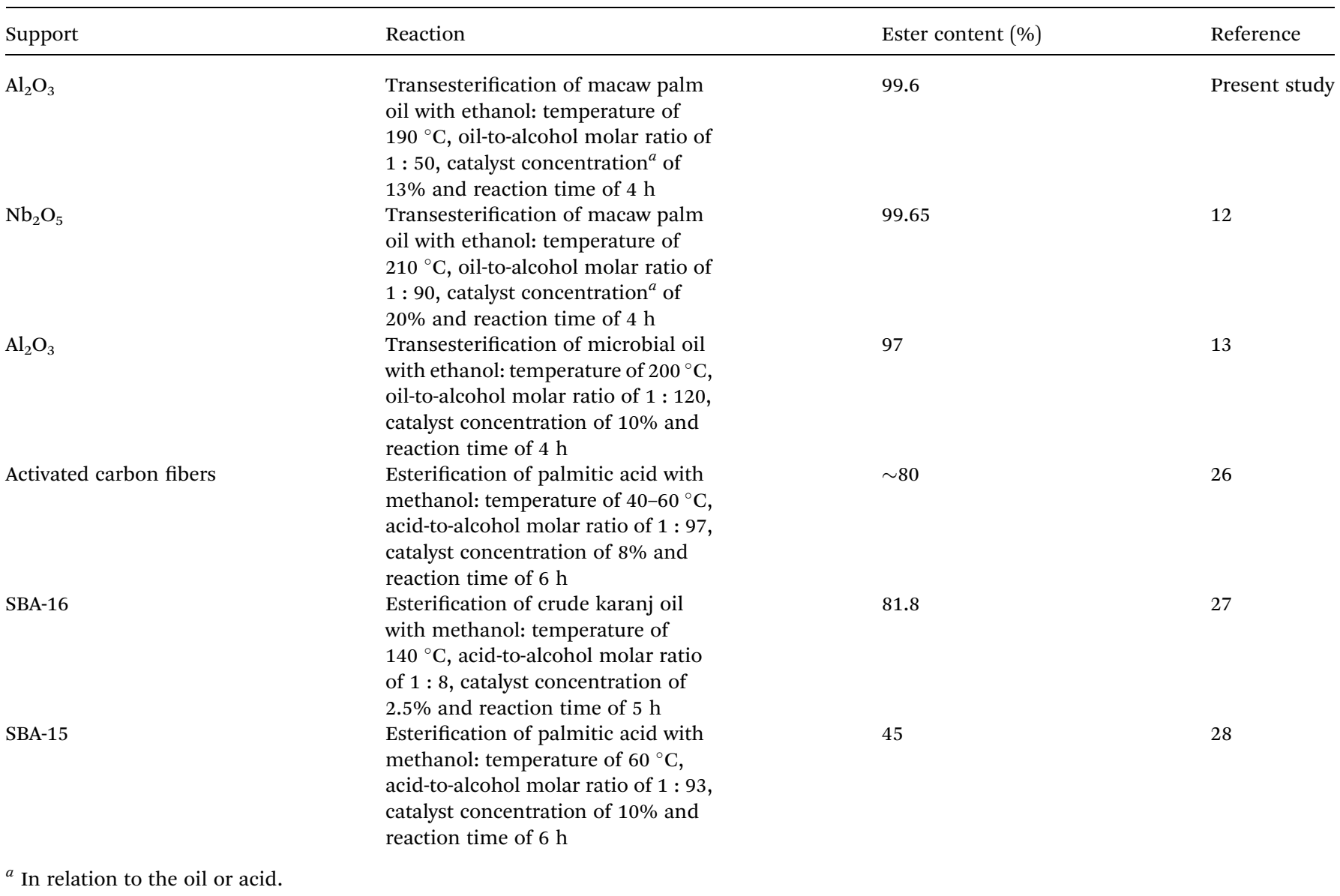

From a process perspective, it can be demonstrated that, albeit still high temperatures and relatively harsh conditions are required for the trans/esterification reaction to occur satisfactorily, the $\mathrm{H}_{3} \mathrm{PMo} / \mathrm{Al}_{2} \mathrm{O}_{3}$ catalyst presents some advantages in comparison with previous reports from the literature. Table 6 resumes some applications of $\mathrm{H}_{3}$ PMo supported on different materials. In summary, it can be seen that even at a lower ethanol-to-oil molar ratio, there is a higher ester production. Especially considering the study on trans/esterification of macaw palm oil using $\mathrm{H}_{3}$ PMo support on $\mathrm{Nb}_{2} \mathrm{O}_{5}$ (ref. 12), it can be clearly seen that lower amounts of catalyst and molar ratio, and lower reaction temperatures are required for the heteropolyacid supported onto $\mathrm{Al}_{2} \mathrm{O}_{3}$ for a similar ester content obtained in the end of the reaction. Therefore, the results described herein may represent an alternative to reaction conditions in which the acid behavior of the catalyst is intrinsically linked to the product formation, as is the case of trans/ esterification reactions of oils with high acid values and in the presence of residual dissolved water.

\section{Conclusions}

The present study has investigated and optimized the effects of different process variables on biodiesel production from macaw palm oil using as catalyst $\mathrm{H}_{3} \mathrm{PMo}$ supported on $\mathrm{Al}_{2} \mathrm{O}_{3}$. The $\mathrm{H}_{3} \mathrm{PMo} / \mathrm{Al}_{2} \mathrm{O}_{3}$ catalyst presented good regeneration and can be reused for up to four reaction cycles with little loss of activity. The results also demonstrated to be robust in terms of reproduction with other high-acid feedstock.

Considering that biodiesel is commercially made from pure and refined vegetable oils or animal fats, the economic and environmental costs of biodiesel production are often questioned in regards to their sustainability. High-acid value oils are those that are likely prone to partial degradation in which part of the triacylglycerol structures are partially or fully hydrolyzed to free fatty acids. These oils cannot undergo through typical operations for producing biodiesel, i.e., through base-catalyzed reactions, as the main product of the reaction would be soap. This work assesses the use of a particular type of solid catalyst for the production of biodiesel through simultaneous esterification of free fatty acids and transesterification of triacylglycerols to fatty acid ethyl esters of fuel grade. The solid catalyst used in this study was a heteropolyacid, which is able to withstand high concentrations of free water in the reaction medium, as well as the presence of free fatty acids. Studies evaluating the performance of heteropolyacids as catalysts often use a solid support in order to increase their reaction and operation stability, which are often based in some metal oxides, 
like titania and zirconia, or other mineral-like structure, as zeolites and activated carbon. In order to potentially drive the costs associated with the preparation of the catalyst, this work assessed the utilization of alumina $\left(\mathrm{Al}_{2} \mathrm{O}_{3}\right)$ as solid support for the catalyst. The use of the alumina-supported heteropolyacid was tested on the reaction of oil extracted from macaw palm, a plant native to Brazil with little commercial applications that provides a high-acid value oil, achieving over $98 \%$ of conversion on the established reaction conditions. The optimized conditions were also tested on other two feedstocks, residual frying oil and fungal single cell oil, demonstrating that the operational conditions are rather robust and can be extrapolated to other oil sources. Therefore, the reaction conditions established, and the engineering premises evaluated on the reaction conditions, are not limited to the use of macaw palm oil, per se, but potentially a wide array of feedstock with little to no commercial value, as residual frying oil.

\section{Conflicts of interest}

There are no conflicts to declare.

\section{Acknowledgements}

This work was supported by the São Paulo Research Foundation (FAPESP) (process numbers 2016/10636-8 and 2017/12907-8), Conselho Nacional de Desenvolvimento Científico e Tecnológico CNPq (Process Number 404812/2013-9) and CAPES (financial code 001).

\section{References}

1 J. Alcañiz-Monge, B. El Bakkali, G. Trautwein and S. Reinoso, Appl. Catal., B, 2018, 224, 194-203.

2 P. Ferreira, I. M. Fonseca, A. M. Ramos, J. Vital and J. E. Castanheiro, Catal. Commun., 2011, 12(7), 573-576.

3 S. Zhu, Y. Zhu, X. Gao, T. Mo, Y. Zhu and Y. Li, Bioresour. Technol., 2013, 130, 45-51.

4 Y. Izumi, K. Hisano and T. Hida, Appl. Catal., A, 1999, 181(2), 277-282.

5 E. Caliman, J. A. Dias, S. C. Dias, F. A. Garcia, J. L. de Macedo and L. S. Almeida, Microporous Mesoporous Mater., 2010, 132(1-2), 103-111.

6 R. Sheikh, M. S. Choi, J. S. Im and Y. H. Park, J. Ind. Eng. Chem., 2013, 19(4), 1413-1419.

7 M. F. M. Yusoff, X. Xu and Z. Gui, J. Am. Oil Chem. Soc., 2014, 91, 525-531.

8 C. Brunschwig, W. Moussavou and J. Blin, Prog. Energy Combust. Sci., 2012, 38, 283-301.
9 C. E. R. Reis, A. K. F. Carvalho, H. B. Bento and H. F. de Castro, Bioresource Technology Reports, 2019, 6, 46-53.

10 L. R. V. da Conceição, L. M. Carneiro, J. D. Rivaldi and H. F. de Castro, Ind. Crops Prod., 2016, 89, 416-424.

11 F. D. Santos, L. R. V. da Conceição, A. Ceron and H. F. de Castro, Appl. Clay Sci., 2017, 149, 41-50.

12 L. R. V. Conceição, L. M. Carneiro, D. S. Giordani and H. F. de Castro, Renewable Energy, 2017, 113, 119-128.

13 A. K. F. Carvalho, L. R. V. Conceição, J. P. A. Silva, V. H. Perez and H. F. de Castro, Fuel, 2017, 202, 503-511.

14 J. P. C. Evangelista, T. Chellappa, A. C. F. Coriolano, V. J. Fernandes Jr, L. D. Souza and A. S. Araujo, Fuel Process. Technol., 2012, 104, 90-95.

15 G. Paglia, C. E. Buckley, T. J. Udovic, A. L. Rohl, F. Jones, C. F. Maitland and J. Connolly, Chem. Mater., 2004, 16, 1914-1923.

16 A. Boumaza, L. Favaro, J. Lédion, G. Sattonnay, J. B. Brubach, P. Berthet, A. M. Huntz, P. Roy and R. Tétot, J. Solid State Chem., 2009, 182, 1171-1176.

17 D. Liu, X. Y. Quek, S. Hu, L. Li, H. M. Lim and Y. Yang, Catal. Today, 2009, 147, 51-57.

18 D. S. Mansilla, M. R. Torviso, E. N. Alesso, P. G. Vázquez and C. V. Cáceres, Appl. Catal., A, 2010, 375, 196-204.

19 S. S. Kale, U. Armbruster, R. Eckelt, U. Bentrup, S. B. Umbarkar, M. K. Dongare and A. Martin, Appl. Catal., A, 2016, 527, 9-18.

20 G. Derringer and R. Suich, J. Qual. Technol., 1980, 12, 214219.

21 C. Ratledge, Biochimie, 2004, 86(11), 807-815.

22 S. C. da Silva Filho, A. C. Miranda, T. A. F. Silva, F. A. Calarge, R. R. de Souza, J. C. C. Santana and E. B. Tambourgi, J. Cleaner Prod., 2018, 183, 1034-1042.

23 M. Khot, S. Kamat, S. Zinjarde, A. Pant, B. Chopade and A. RaviKumar, Microb. Cell Fact., 2012, 11(1), 71.

24 E. A. Canesin, C. C. de Oliveira, M. Matsushita, L. F. Dias, M. R. Pedrão and N. E. de Souza, Electron. J. Biotechnol., 2014, 17(1), 39-45.

25 A. Talebian-Kiakalaieh, N. A. S. Amin, A. Zarei and I. Noshadi, Appl. Energy, 2013, 102, 283-292.

26 J. Alcañiz-Monge, G. Trautwein and J. P. Marco-Lozar, Appl. Catal., A, 2013, 468, 432-441.

27 M. S. Khayoon and B. H. Hameed, Fuel Process. Technol., 2013, 114, 12-20.

28 A. I. Tropecêlo, M. H. Casimiro, I. M. Fonseca, A. M. Ramos, J. Vital and J. E. Castanheiro, Appl. Catal., A, 2010, 390, 183189. 